\title{
Kiat Mengatasi Kecemasan pada Masa Pandemi COVID-19
}

\author{
Hendrawati $^{*}$, Iceu Amira ${ }^{2}$, Sukma Senjaya ${ }^{3}$, Udin Rosidin ${ }^{4}$ \\ Universitas Padjadjaran, Jl. Raya Bandung - Sumedang No.KM. 21, Hegarmanah, Kec. Jatinangor, \\ Kabupaten Sumedang, Jawa Barat 45363 \\ Email: hendrawatids@gmail.com ${ }^{\mathbf{1 *}}$
}

(Diajukan: 30 September 2021, Direvisi: 08 Oktober 2021, Diterima: 06 November 2021)

\begin{abstract}
ABSTRAK
Pandemi COVID-19 saat ini berdampak pada semua tatanan kehidupan manusia. Kasus COVID-19 yang terus meningkat pada saat ini membuat semua negara menerapkan kebijakan memberlakukan pembatasan kegiatan masyarakat untuk mencegah penyebaran virus Corona. Di Indonesia pemerintah menerapkan kebijakan diantanranya pembatasan sosial berskala besar untuk menekan penyebaran virus ini. Adanya pandemi COVID-19 tersebut membuat masyarakat mengalami ketakutan dan merasa tidak aman dan nyaman karena hampir setiap hari kasus COVID-19 terus bertambah. Orang yang positif COVID-19 dan angka kematian yang meningkat berdampak pada gangguan kesehatan psikososial yaitu kecemasan. Tujuan dari pelaksanaan kegiatan pengabdian pada masyarakat ini adalah untuk meningkatkan pengetahuan masyarakat dalam mengatasi kecemasan dampak COVID-19. Sehingga masyarakat merasa aman dan nyaman dalam menghadapi pandemi COVID-19 ini. Metode yang digunakan dalam kegiatan ini adalah pelaksanaan pendidikan kesehatan dengan menggunakan media ceramah, diskusi dan simulasi. Hasil kegiatan menunjukkan adanya peningkatan rata rata nilai pengetahuan peserta sebelum dan sesudah dilaksanakan pendidikan kesehatan. Rata rata nilai pengetahuan peserta sebelum dilakukan pendidikan kesehatan adalah 56 dan setelah dilakukan pendidikan kesehatan meningkat mejadi 80. Peningkatan pengetahuan masyarakat dalam mengatasi kecemasan pada masa pandemi COVID-19 ini berdampak pada peningkatan kemampuan masyarakat dalam menjalankan protokol kesehatan COVID-19 dan melaksanakan perilaku hidup sehat secara mandiri.
\end{abstract}

\section{Kata Kunci : Pendidikan kesehatan, Kecemasan, Pandemi COVID-19}

\section{ABSTRACT}

The current COVID-19 pandemic has an impact on all aspects of human life. The increasing number of COVID-19 cases at this time has forced all countries to implement policies to impose restrictions on community activities to prevent the spread of the Corona virus. In Indonesia, the government has implemented policies including Large-Scale Social Restrictions to suppress the spread of this virus. The existence of the COVID-19 pandemic has made people experience fear and feel insecure and comfortable because almost every day the number of COVID-19 cases continues to grow. People who are positive for COVID-19 and the increasing mortality rate has an impact on psychosocial health disorders, namely anxiety. The purpose of implementing this community service activity is to increase public knowledge in overcoming anxiety about the impact of COVID-19. So that people feel safe and comfortable in the face of this COVID-19 pandemic. The method used in this activity is the implementation of health education using lectures, discussions and simulations. The results of the activity showed an increase in the average value of participants' knowledge before and after the implementation of health education. The average knowledge value of participants before health education was carried out was 56 and after health education increased to 80. Increased public knowledge in dealing with anxiety during the COVID-19 pandemic has an impact on increasing the community's ability to carry out COVID-19 health protocols and carry out healthy lifestyles independently.

Keywords: Health Education, Anxiety, COVID-19, Pandemic 


\section{PENDAHULUAN}

Pandemi COVID-19 yang sedang terjadi di seluruh negara menyebabkan banyak perubahan dalam tatanan kehidupan manusia. Kini semua kegiatan dilakukan dari rumah. Sehingga semua orang tidak bebas melakukan aktivitas seperti biasanya. Selain itu untuk menjalin komunikasi antar pribadi dalam menjalankan kehidupannya harus selalu dari rumah, membatasi acara kumpul bersama, menjaga jarak jika harus ke luar rumah dan menutup hidung serta mulut dengan masker demi terhindar dari segala macam virus. Selain membawa beberapa perubahan pada sendi-sendi kehidupan manusia, COVID-19 juga membawa beberapa dampak lain seperti ekonomi yang semakin melemah dan kebutuhan yang semakin meningkat. Keterbatasan ruang gerak dan banyaknya halangan membuat semua orang juga bingung harus berbuat apa. Perubahan-perubahan yang terjadi serta dampak tersebut membuat setiap orang harus beradaptasi dan berusaha menerimanya. Namun, tidak semua orang mampu untuk beradaptasi dan menerima situasi yang sedang terjadi, pada akhirnya itu semua akan bermuara menjadi stres.

Stres adalah kondisi ketika individu berada dalam situasi yang penuh tekanan atau ketika individu merasa tidak sanggup mengatasi tuntutan yang dihadapinya (Kaptein et al. 2018). Dampak dari stres diantaranya adalah kecemasan berlebih atau anxiety. Kecemasan merupakan keadaan emosi yang muncul saat individu sedang stress dan ditandai oleh perasaan tegang, pikiran yang membuat individu merasa khawatir dan disertai respon fisik (jantung berdetak kencang, naiknya tekanan darah, dan lain sebagainya (Fitria dan Ifdil 2020).

Hasil pengamatan yang dilakukan tim pelaksana pengabdian dan survey yang dilakukan delapan orang mahasiswa Fakultas Keperawatan Universitas Padjadjaran ditemukan beberapa keluhan yang sering terjadi di masyarakat. Keluhan yang sering ditemukan pada saat kondisi pandemi sekarang ini diantaranya adalah sulit untuk berpikir jernih, tidak mampu melakukan hal-hal bermanfaat, sulit tidur, sulit menikmati kegiatan sehari-hari, selalu kelelahan, kehilangan minat terhadap hal-hal yang sebelumnya menarik, mudah lelah saat mengerjakan sesuatu, dan pekerjaan terganggu. Selain itu ada juga yang mengeluh merasa tegang, cemas atau khawatir, merasa tidak bahagia, bahkan ada yang mempunyai pikiran untuk mengakhiri hidupnya.

Kondisi tersebut sudah menggambarkan bahwa gangguan kecemasan akibat pandemi COVID-19 sudah melanda masyarakat. Kecemasan adalah perasaan tidak menyenangkan yang muncul dari reaksi ketegangan di dalam tubuh (Hayat 2017). Kecemasan merupakan 
keadaan gelisah atau keadaan khawatir yang memungkinkan bahwa sesuatu yang buruk akan segera terjadi yang ditandai dengan persaan tegang, khwatir, resah, gelisah, takut, gugup dan berkeringat (Dewi 2020).

Secara umum ada 3 gejala yang bisa menandakan seseorang terinfeksi COVID-19, yaitu demam (suhu tubuh diatas $38^{0} \mathrm{C}$ ), batuk kerng, sesak nafas. Gejala lain yang jarang terjadi, tetapi muncul pada infeksi COVID-19 yaitu mudah lelah, nyeri otot, nyeri dada, sakit tenggorokan, sakit kepala, mual atau muntah, diare, pilek, atau hidung tersumbat, menggigil, bersin bersin, hilangnya kemampuan mengecap rasa, atau mencium bau. Dari berbagai gejala COVID-19 tersebut akan menimbulkan gangguan psikososial individu dan keluarganya. Gangguan psikososial tersebut terjadi karena individu atau keluarga harus melakukan isolasi mandiri satu keluarga selama 2 minggu. Memperhatikan permasalahan tersebut maka masyarakat akan terancam oleh rasa kecemasan yang terus menerus menghantuinya. Apabila hal tersebut dibiarkan akan berdampak pada masalah kesehatan masyarakat secara umum. Upaya untuk mengatasi permasalahan tersebut perlu dilakukan kegiatan yang membantu masyarakat untuk mengatasi kecemasannya.

Kegiatan yang dilakukan diawali dengan identifikasi masalah yang dirasakan oleh masyarakat dan keluarga. Hasil analisis dan pengamatan yang dilakukan oleh tim pengabdian menunjukkan adanya keterbatasan pemahaman masyarakat tentang upaya yang bisa dilakukan untuk mengatasi kecemasan tersebut. Masyarakat membutuhkan informasi dan pengetahuan yang benar tentang cara mengatasi permasalahan yang sedang dirasakan pada masa pandemi COVID-19 ini.

Promosi kesehatan merupakan kegiatan yang sangat tepat dan dibutuhkan oleh masyarakat yang berkaitan dengan menguatkan psikologis individu dan keluarga, supaya tidak terjadi kepanikan dan ketakutan yang berlebihan yaitu dengan cara: tarik nafas dalam, membangun pikiran positif, latihan otot progesif berfokus pada lima jari, membangun spiritual, hati yang gembira (Rusman, Umar, dan Majid 2021). Berdasarkan permasalahan tersebut maka tim pengabdian melaksanakan kegiatan pendidikan kesehatan kepada masyarakat dengan thema kegiatan yaitu Kiat Mengatasi Kecemasan Pada Masa Pandemi COVID-19. Tujuan kegiatan ini adalah meningkatkan pemahaman masyarakat tentang kiat untuk mengatasi kecemasan saat pandemi COVID-19.

\section{METODE}

Metode kegiatan yang dilakukan dalam kegiatan ini menggunakan pendekatan tulang ikan. Dengan metode ini kegiatan yang dilaksanakan akan sesuai dengan kebutuhan yang 
dirasakan oleh masyarakat pada saat pandemi COVID-19. Langkah pertama pendekatan tulang ikan kegiatan pengabdian pada masyarakat ini adalah melaksanakan identifikasi permasalahan yang dialami oleh masyarakat dan keluarga tentang dampak COVID-19. Permasalahan-permasalahan yang telah diidentifikasi kemudian dilakukan analisis dan hasil analisis kemudian disusun dalam skala prioritas masalah yang harus diselesaikan. Masalah yang terpilih sebagai prioritas utama kemudian diselesaikan bersama dengan keluarga. Sebelum melaksanakan pendidikan kesehatan tim pengabdian melakukan koordinasi dengan masyarakat yang berniat untuk mengikuti pendidikan kesehatan. Sosialisasi kegiatan dilaksanakan melalui whatsapp, facebook dan media sosial lainnya. Dalam pelaksanaan pendidikan kesehatan dilakukan secara daring dengan menggunakan metode ceramah, diskusi, membuka konsultasi. Sasaran kegiatan adalah masyarakat umum yang tertarik dengan kegiatan pendidikan kesehatan.

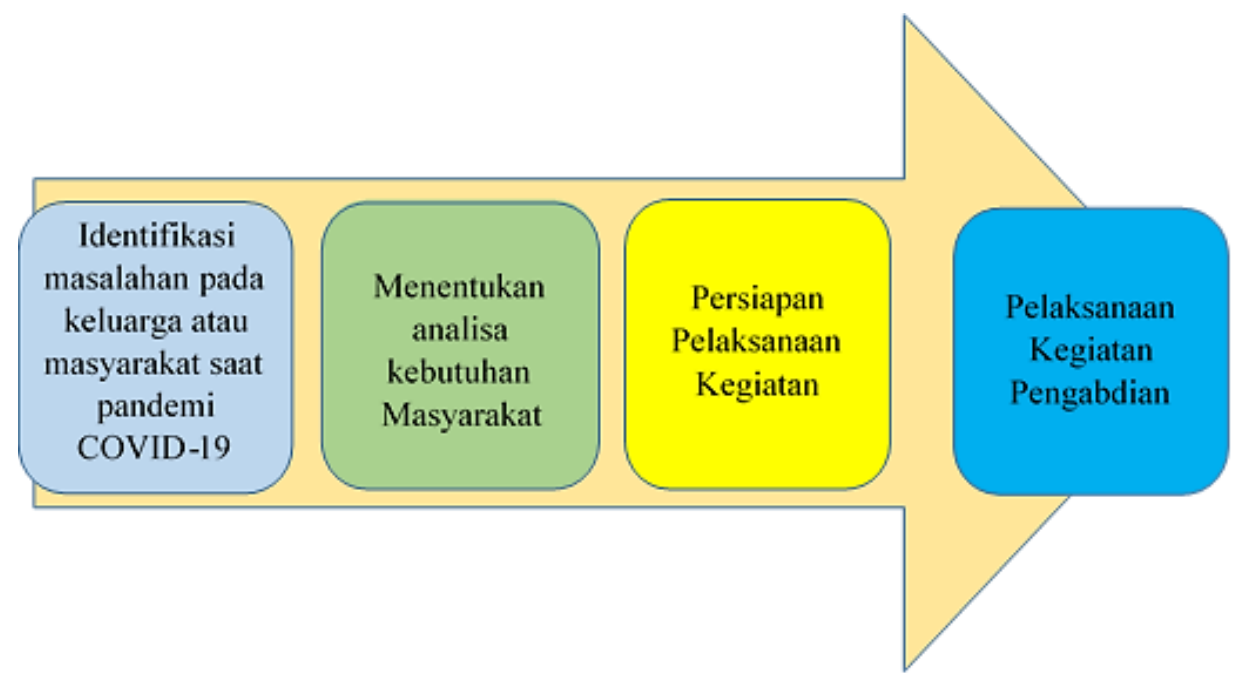

Gambar 1. Alur Metode Kegiatan

\section{HASIL, PEMBAHASAN DAN DAMPAK}

Masa pandemi COVID-19 berdampak pada permasalahan di masyakarat baik sosial ekonomi maupun kesehatan. Hasil identifikasi permasalahan yang dilakukan oleh mahasiswa melalui survey online menunjukkan kecemasan merupakan masalah yang banyak ditemukan. Dengan kecemasan yang dialami oleh banyak masyakat bisa berdampak pada masalah kesehatan lainnya seperti rasa khawatir, sulit tidur dan lain sebagainya. Hasil analisis masalah menunjukkan adanya ketidaktahuan masyarakat tentang bagaimana cara mengatasi kecemasan tersebut. Menurut (Notoatmodjo 2019) untuk meningkatkan pengetahuan masyarakat tentang perilaku kesehatan adalah dengan cara pendidikan kesehatan. Persiapan 
kegiatan diawali dengan menyusun rencana kegiatan, menyusun materi dan menyebarluaskan informasi kepada calon peserta.

Pelaksanaan kegiatan berupa pendidikan kesehatan yang dilakukan secara daring dengan tujuan meningkatkan pengetahuan dan pemahaman masyarakat dalam mengenal kiat mengatasi kecemasan dan mencegah terjadinya gangguan psikososial dan gangguan Jiwa akibat pandemi COVID-19. Pendidikan kesehatan dilaksanakan pada hari Senin tanggal 18 Mei 2020 pukul 13.00 s/d 15.00 WIB. Peserta yang mengikuti kegiatan sebanyak 120 orang. Lokasi peserta tersebar di daerah Garut, Bandung, Tangerang, Jakarta dan Lampung. Media yang digunakan dalam pendidikan kesehatan tersebut adalah ceramah dengan media gambar, foto dan video sebagai bahan utama. Media pendidikan kesehatan lainnya adalah dengan media simulasi atau permainan yang merupakan pelengkap. Permainan dibuat untuk meningkatkan pemahaman peserta mengenai kiat mengatasi kecemasan pada masa pandemi COVID-19. Penggunaan media ini bertujuan untuk menentukan tingkat pengetahuan peserta sebelum dan sesudah melakukan pendidikan kesehatan.

Hasil kegiatan dievaluasi dengan metode uji mann whitney. Metode ini merupakan uji non-parametris yang dipakai sebagai perbandingan dua mean populasi yang berasal dari populasi yang sama (Lukiastuti 2012). Proses perhitugan dengan cara membandingkan rata rata nilai pengetahuan sebelum dan sesudah dilaksanakan pendidikan kesehatan. Hasil menunjukkan bahwa bahwa rata rata nilai pengetahuan peserta sebelum dilakukan pendidikan kesehatan adalah 56 dan setelah dilakukan pendidikan kesehatan meningkat menjadi 80. Peningkatan pengetahuan tersebut terbentuk karena meningkatnya pemahaman masyarakat tentang cara mengatasi kecemasaan secara mandiri. Mayarakat memahami cara melakukan tarik nafas dalam, membangun pikiran positif, membangun spiritual dan hati yang gembira. Peningkatan pengetahuan masyarakat tersebut merupakan potensi yang baik dalam meningkatkan pemahaman masyarakat dalam mengendalikan kecemasan tersebut. Apalagi pandemi COVID-19 ini sangat berdampak pada semua tatanan kehidupan manusia. Dengan pelaksanaan pendidikan kesehatan diharapkan kemampuan masyarakat meningkat dalam mengatasi kecemasan saat pandemi COVID-19. Menurut (Wijayanti dan Mulyadi 2018) pendidikan kesehatan dapat meningkatkan pengetahuan dan pemahaman seseorang.

Keberhasilan kegiatan pendidikan kesehatan tentang kiat mengatasi kecemasan pada masa COVID-19 merupakan materi yang sangat tepat dilakukan pada saat ini. Masalah penyebaran COVID-19 jangan dianggap hal yang sepele, karena ini akan mempengaruhi kehidupan individu, keluarga, masyarakat dan mempemgaruhi keadaan 
social, ekonomi, spiritual, pendidikan dan kehidupan sehari-hari. Pandemi COVID-19 sangat berdampak pada sebagian besar kehidupan masyarakat dan tidak semua masyarakat dapat menyesuaikan dengan situasi yang dihadapinya (Rinaldi dan Yuniasanti 2020). Masalah yang sering ditemukan pada masa pandemi COVID-19 adalah kecemasan. Menurut penelitian yang dilakukan oleh (Rusdiatin 2021) kecemasan merupakan dampak dari pandemi COVID-19, masyarakat merasa cemas karena kasus COVID-19 yang terus meningkat, takut ketularan COVID-19 dan tidak leluasa keluar rumah. Materi tentang kiat mengatasi kecemasan pada masa pandemi COVID-19 merupakan informasi dan pengetahuan yang sangat penting dan tepat bagi masyarakat.

Menurut (Rusman, Umar, dan Majid 2021) ada beberapa hal yang perlu di lakukan dalam mengatasi kecemasan tersebut dan sangat mudah untuk dilakukan yaitu dengan cara tarik nafas dalam, membangun pikiran positif, latihan otot progesif, berfokus pada lima jari, membangun spiritual dan hati yang gembira. Kiat lain adalah dengan cara satukan jempol dengan telunjuk kemudian bayangkan saat badan sehat dan tidak ada gangguan apapun. Satukan jempol dengan jari tengah kemudian bayangkan orang yang kita sayangi dan sangat perhatian. Bayangkan betapa mereka peduli pada kita. Satukan jempol dengan jari manis dan bayangkan saat kita mendapat pujian atau mendapat prestasi. Satukan jempol dengan jari kelingking kemudian bayangkan kita berada ditempat yang kita sukai. Misalnya di pinggir pantai dipagi hari. Materi yang tepat dan sesuai dengan kebutuhan masyarakat akan meningkatkan motivasi peserta untuk mengikuti kegiatan secara maksimal (Rimbarizki dan Susilo 2017).

Selain materi yang sesuai dengan kebutuhan masyarakat, faktor lain yang mendukung terhadap keberhasilan kegiatan pendidikan kesehatan adalah penggunaan media yang tepat. Kegiatan pendidikan kesehatan yang digunakan adalah gambar, foto dan video dan simulasi. Media yang digunakan dalam kegiatan ini sangat cocok untuk peserta. Materinya yang diberikan sangat menarik dan mudah diterima oleh masyarakat peserta pendidikan kesehatan sehingga akan lebih mudah dipahami oleh masyarakat. Pemilihan media yang tepat dapat meningkatkan pemahaman masyarakat peserta kegiatan (Farida 2015). Peserta pendidikan kesehatan antusias saat pemberian materi berlangsung. Peserta mengikuti kegiatan dengan senang hati karena pendidikan kesehatan dilaksanakan dengan menyenangkan. Kegiatan berjalan kondusif karena peserta memperhatikan materi yang disampaikan dengan baik. Hal ini dibuktikan dengan banyaknya peserta yang tertarik untuk bertanya dan menjawab pertanyaan ketika sesi tanya jawab. 


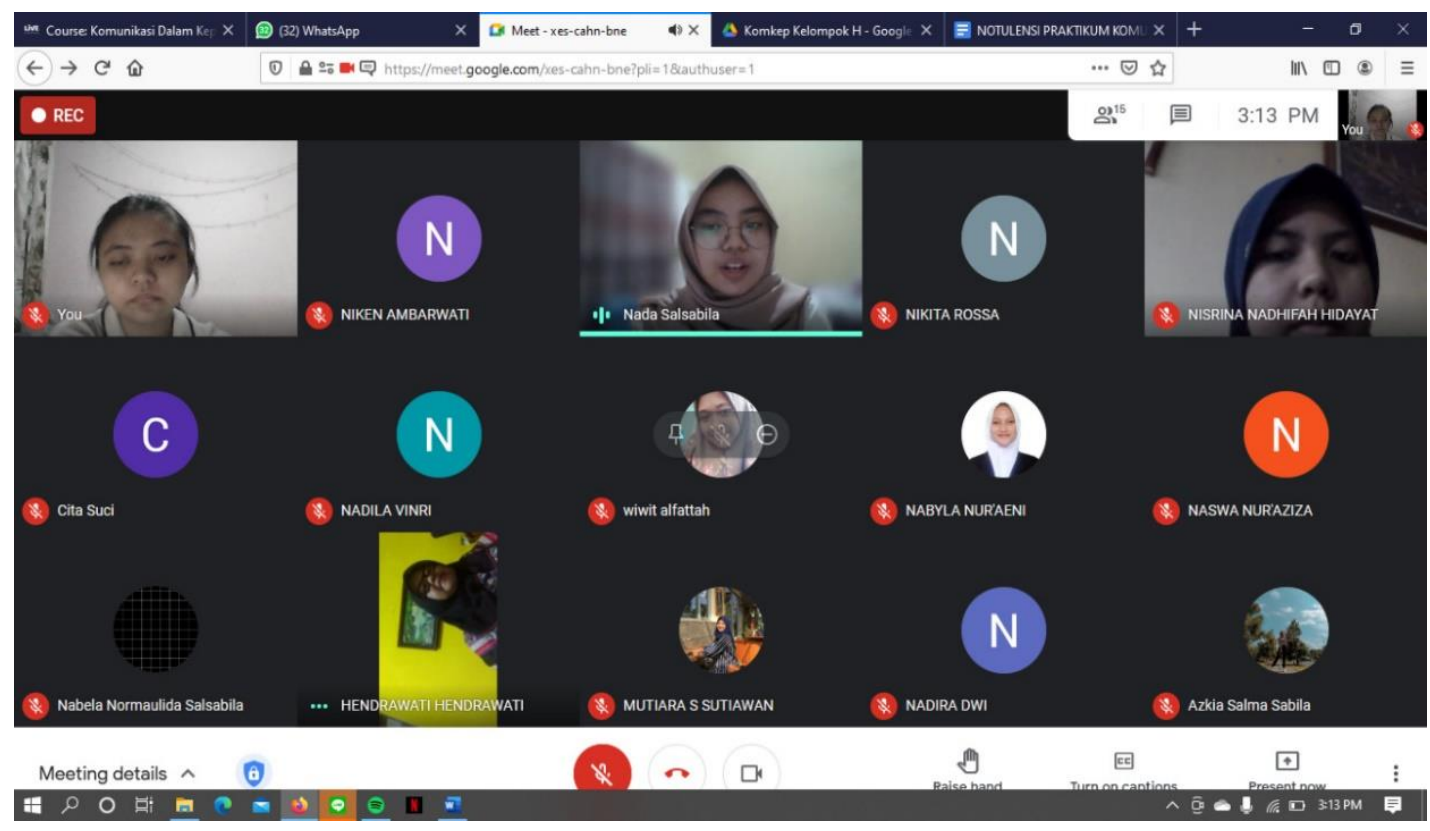

Gambar 2 Kegiatan Pendidikan Kesehatan Secara Daring

Peningkatan pengetahuan masyarakat tentang kiat mengatasi kecemasan dalam menghadapi pandemi COVID-19 diperkuat oleh penggunaan simulasi atau permainan dalam kegiatan pendidikan kesehatan. Setelah diberikan materi melalui ceramah peserta kegiatan dibimbing secara langsung melakukan simulasi dengan gerakan dan pemusatan pikiran untuk mengatasi kecemasan tersebut. Dengan disimulasikan gerakan gerakan tersebut, peserta kegiatan dapat mempraktekan secara langsung cara cara mengatasi kecemasan akibat pandemi COVID-19. Pendidikan kesehatan yang dilaksanakan dengan menggunakan media ceramah dan simulasi dapat mempercepat peningkatan pemahaman masyarakat terhadap materi yang diberikan (Amanda, Rosidin, dan Permana 2020). Gerakan yang dipraktekan diantaranya adalah belajar nafas dalam, menutup mata dan berpikir fokus serta berpikir positif melalui simbol jari.

Mengatasi kecemasan dengan menarik nafas dalam merupakan salah satu kiat yang mudah dilaksanakan. Menarik nafas dalam secara teratur dapat meningkatkan dan memperbaiki pengiriman oksigen ke seluruh organ tubuh. Rutin menarik nafas dalam telah terbukti menurunkan tekanan darah. Hal ini dikarenakan nafas dalam merupakan suatu usaha untuk inspirasi dan ekspirasi sehingga berpengaruh terhadap peregangan kardiopulmonari. Peregangan tersebut akan memicu peningkatan saraf parasimpatis dan menghambat pusat simpatis. Saraf parasimpatik berfungsi mengendalikan fungsi denyut jantung sehingga membuat tubuh rilek (Aprianto, Kristiyawati dan Purnomo 2013). 
Pentingnya kemampuan masyarakat dalam mengatasi kecemasan saat pandemi COVID-19 sangatlah penting untuk ditingkatkan. Dampak kecemasan dapat menetap bahkan meningkat meskipun situasi yang mengancam tidak ada. Kecemasan yang berlebihan dapat mempunyai dampak yang merugikan pada pikiran serta tubuh bahkan dapat menimbulkan penyakit-penyakit fisik (MELLU 2020). Memperhatikan hal terbut sangatlah berdampak positif dari kegiatan pendidikan kesehatan ini. Peningkatan pengetahuan yang dicapai dalam pendidikan kesehatan ini akan menjadi potensi awal masyarakat untuk dapat mengatasi kecemasan yang dirasakannya. Masyarakat akan berupaya untuk melaksanakan gerakan gerakan yang diajarkan oleh tim pelaksana pengabdian. Dengan dipahaminya kiat mengatasi kecemasan tersebut maka masyarakat akan mampu secara mandiri untuk beradaptasi dengan kondisi pandemi COVID-19 dan melaksanakan pencegahan COVID-19 dengan baik. Maka dampak selanjutnya adalah masyarakat dapat meningkatkan kemampuannya dalam memelihara kesehatan secara mandiri.

Membangun kesadaran masyarakat dalam perilaku pencegahan COVID-19 sangat diperlukan. Hal ini akan dapat terwujud apabila masyakat memahami dengan baik cara mengatasi kecemasan akibat COVID-19. Oleh karena itu perlu dipertahankan atau mungkin ditingkatkan kemampuan setiap masyarakat dalam mengatasi kecemasannya. Protokol kesehatan dalam pencegahan COVID-19 dapat dilaksanakan dengan baik apabila masyarakat tidak berada dalam situasi kecemasan. Upaya peningkatan pengetahuan masyarakat dalam mengatasi kecemasan dapat dilakukan oleh berbagai pihak seperti dinas dan instansi terkait di daerah. Dukungan kesehatan jiwa dan psikososial sangat membantu dalam penanganan yang berkaitan dengan kecemasan yang sering terjadi dimasyarakat. Hampir semua anggota keluarga menyatakan dengan adanya pandemi COVID-19 ini merasa takut dan tidak bisa tidur, sering berprasangka buruk terhadap orang yang ditemui atau tetangga yang datang ke rumah. Sehingga sosialisasi dengan tetangga dan orang lain terganggu. Untuk mencapai keberhasilan kiat mengatasi kecemasan pada masa pandemi COVID-19 sangat diperlukan adanya koordinasi dari bebagai pihak yang terkait. Pihak yang utama adalah puskesmas, keluarga, masyarakat dan pemerintah setempat/satgas COVID-19 (Kemenkes 2020).

\section{SIMPULAN}

Pelaksanaan kegiatan pengabdian kepada masyarakat berjalan dengan lancar. Kegiatan pengabdian ini merupakan integrasi kegiatan mahasiswa dan tim pengabdian 
dari dosen. Hasil kegiatan pendidikan kesehatan menunjukan adanya peningkatan pengetahuan masyarakat sebesar 24 point. Hal ini menunjukan bahwa sosialisasi dan edukasi tentang kiat mengatasi kecemasan pada masa COVID-19 dapat meningkatkan pemahaman dan pengetahuan peserta.

\section{UCAPAN TERIMAKASIH}

Kegiatan yang berjudul "Kiat mengatasi kecemasan pada masa pandemi COVID19" dapat berjalan dengan baik atas dukungan dari berbagai pihak. Oleh karena itu penulis ingin mengucapkan terimakasih yang sebesar-besarnya kepada: Rektor Universitas Padjadjaran, Dekan Fakultas Keperawatan Unpad, dan seluruh pihak yang penulis tidak bisa sebutkan satu persatu. Akhir kata penulis ucapkan, semoga kebaikan yang dilakukan oleh pihak-pihak diatas dibalas oleh Allah SWT, Aamiin.

\section{DAFTAR PUSTAKA}

Amanda, Sri, Udin Rosidin, dan Ryan Hara Permana. 2020. "Pengaruh Pendidikan Kesehatan Senam Diabetes Melitus Terhadap Pengetahuan Kader Kesehatan." Media Karya Kesehatan 3(2).

Aprianto, Dino, Sri Puguh Kristiyawati, dan S Eko Ch Purnomo. 2013. "Efektifitas Teknik Relaksasi Imajinasi Terbimbing Dan Nafas Dalam Terhadap Penurunan Kecemasan Pada Pasien Pre Operasi." Karya Ilmiah.

Dewi, Wahyu Aji Fatma. 2020. "Dampak Covid-19 Terhadap Implementasi Pembelajaran Daring Di Sekolah Dasar.” Edukatif: Jurnal Ilmu Pendidikan 2(1): 55-61.

Farida, Farida. 2015. "Mengembangkan Kemampuan Pemahaman Konsep Peserta Didik Melalui Pembelajaran Berbasis VCD." Al-Jabar: Jurnal Pendidikan Matematika 6(1): 25-32.

Fitria, Linda, dan Ifdil Ifdil. 2020. "Kecemasan Remaja Pada Masa Pandemi Covid-19." Jurnal EDUCATIO: Jurnal Pendidikan Indonesia 6(1): 1-4.

Hayat, Abdul. 2017. "Kecemasan Dan Metode Pengendaliannya." Khazanah: Jurnal Studi Islam Dan Humaniora 12(1).

Kaptein, Ad A, Brian M Hughes, Michael Murray, dan Joshua M Smyth. 2018. "Start Making Sense: Art Informing Health Psychology." Health psychology open 5(1): 2055102918760042.

Kemenkes. 2020. "Pedoman Pencegahan Dan Pengendalian Covid 19." Kementrian Kesehatan RI. Diambil dari: https://covid19.kemkes.go.id/protokol-covid-19/kmkno-hk-01-07-menkes-413-2020-ttg-pedoman-pencegahan-dan-pengendalian-covid$\underline{19}$

Lukiastuti, Fitri. 2012. "Statistik Non Parametris." Telkom University. Diambil dari: 
https://openlibrary.telkomuniversity.ac.id/pustaka/16962/statistika-non-parametrisaplikasi-dalam-bidang-ekonomi-dan-bisnis.html

Mellu, Artanty. 2020. "Gambaran Tingkat Kecemasan Mahasiswa Universitas Citra Bangsa Dalam Menghadapi Pandemi COVID-19 Di Kota Kupang."

Notoatmodjo, Soekidjo. 2019. "Promosi Kesehatan Dan Ilmu Perilaku.” Rineka Cipta.

Rimbarizki, Rimbun, dan Heryanto Susilo. 2017. "Penerapan Pembelajaran Daring Kombinasi Dalam Meningkatkan Motivasi Belajar Peserta Didik Paket C Vokasi Di Pusat Kegiatan Belajar Masyarakat (PKBM) Pioneer Karanganyar.” J+ Plus Unesa $6(2)$.

Rinaldi, Martaria Rizky, dan Reny Yuniasanti. 2020. "Kecemasan Pada Masyarakat Saat Masa Pandemi Covid-19 Di Indonesia." COVID-19 dalam Ragam Tinjauan Perspektif: 137-50.

Rusdiatin, Ivana Eko. 2021. "Gambaran Tingkat Kecemasan Masyarakat Dalam Menghadapi Situasi Pandemi Covid-19." Jurnal Kampus STIKES YPIB Majalengka 9(1): 1-6.

Rusman, Ayu Dwi Putri, Fitriani Umar, dan Makhrajani Majid. 2021. COVID-19 Dan Psikososial Masyarakat Di Masa Pandemi. Penerbit NEM.

Wijayanti, Wijayanti, dan Budhi Mulyadi. 2018. "Pendidikan Kesehatan Menggunakan Booklet Terhadap Pemahaman Pasien Hipertensi Di Puskesmas." Jurnal Ilmiah Ilmu Keperawatan Indonesia 8(01): 372-739. 